\section{THE HARVEIAN ORATION,}

\section{HISTORY AND PROGRESS OF MEDICINE.}

Delivered before the Royal College of Physicians of Loudon, Monday, October 19th, 1885.

BY RICHARD QUAIN, M.D., F.R.C.P., F.R.S.; Consulting Physician to the Bospital for Consumption and Diseases of the Chest at Brompton, etc.

Foundation of the Harrcian Oration. - Recent Harecian Orations. Choice of a Subject. - To search out the Secrets of Naturc. - Why is Medicine deprecialed? - What Prospect for the Fiuture?-Difficulties incident to the Healing Art.-Extrinsic Causes of Disercdit on our Profession. - Expressions of Adverse Opinion._Origin and Conerse of the Bealing Art.-Revival of Scicnce and Learning.-Linacre and the Foundation of the College of Physicians. - Progress of Medical Science subsequent to the Foundation of the Collegr. -Sources and Phases of Superstition. - Relics, Talismans, and Amulets. - Astrology and Alchemy. - The Royal Touch. - Credulity. - Aspect of the College in relation to Superstitious Practices.-Modern Systcms. Cullen, Broun, Broussais. Homcopathy. - The Infuence of Superstition rend Systcm in discrediting the Healing Art._Limits rcachcd by Observers before the Prescnt Age. -Direction of the Change that has occurred. - Anatomy and Histology. - Physiology. - Pathology. -Etiology.-Illustration of Prcventive Medicine.-Cattle.Plague.Cholcra.-Small-pox.-Progress of Pathology. - The work of the Pathological Socicty. - Norbid Anatomy._MIorbid Processes. - Parasitic Pathology. - Experimental Pathology. - Instruments of Diagnosis. - Spccial Progress in Diagnosis. - Therapcutics. - Two Dircetions of its Advance. - Introduction of Anasthetics. - Spccial Drugs. - Futurc Prospects of Therapeutics. - Rctarding Circumstances. - By Experi. mental Pharmacology. - Position of the College in respect to Therapeutic Rescarch.-Evidence of the Improvement claimed.-Diminished Mortality. - In Spccial Diseascs. - In the Army._Diminished Sichncss.

Founclation of the Harveian Oration. - President and Gentlemen,-It is known to the majority, or even to all, of those whom I have now the honour to address, that our great ancestor Harvey, when he conveyed by indenture his patrimonial estate to our College, made that conveyance subject to certain trusts. One of these trusts, sir, had reference to the duty of to-day, which, at your request, I am about to cndeavour to discharge.

Save for a few brief periods of intermission, this duty has been fulfilled annually since the year 1656, when the first Harveian Oration was delivered by Dr. Edward Emily. In the long roll of those who have succeeded this first Harveian Oration, we find the names of many Fellows who have been highly distinguished, not only in the annals of our College, but also in the still wider annals of English science and literature. To follow such eminent men, in the discussion of subjects on which little that is new can now remain to be said, is an undertaking from which I should naturally have recoiled. But, remembering, sir, that the request proceeded from you, the distin. guished President of our College, once a fellow-student, always a friend, I felt that it was no longer open to me even to hesitate. I felt that I must adopt the words of the Controller Calonne, who, when asked by Queen Marie Antoinette to undertake a duty which Her Majesty considered to be difficult, replied, "If it be only difficult, it is done; if it be impossible, it shall be done." In the spirit which suggested his answer I am here; and I crave the indulgence of my hearers whilst I address myself to my task.

lecent Harveian Orations. - For more than twenty years, I have listened with attention to successive Harveian Orations, and I have read with care those which have been published during the same period. I have scarcely known which most to admire : the patient research on which these orations have been founded, the philosophic spirit which has breathed through them, or the eloquent and impressive manner in which the conclusions of the authors have been laid before the College. Some of $\mathrm{my}$ predecessors have reminded us of Harvey's personal history and surroundings. By others, we have been told what was known of the circulation of the blood before his [1295] time; and his method of research and his calm inductive reasoning have been admirably portrayed. By others, again, Harvey's claims to originality in relation to his great discovery have been fully set forth; and have been established with a certainty which can never be disturbed. In one of these brilliant discourses, his observations on Generation found an able and fitting exponent. On another occasion, his philosophy, more especially with reference to the doctrine of final causes, was admirably discussed. On another, the bearing of his discovery upon the improved knowledge of therapeutics, and the better practice of medicine which has resulted from it, was fully described and the grcat philosopher was regarded in the light of a physician as well as in that of a physiologist; while we seem still to listen to the oration of last year, in which Harvey was represented as having anticipated some of the great discoveries which mark the present period. Reflecting on these admirable discourses, I felt that it would be in. possible for me to retraverse such familiar ground, otherwise than at the risk of reminding many of my audience how often they had already heard the same story, related in a more eloquent and a moro impressive form.

Choice of $a$ Subject. - Meditating, then, on the subject on which I should address you to-day, I remembered that I should have before me the portrait of our great predecessor, who might for a moment be assumed to animate the picture, and to be prepared to listen to what I had to say. And venturiu: then to ask myself what the founder of this Öration would most desire to hear, it scemed to me that he would say-as might be anticipated from a character so unassuming, so simple, so opposed to ostentation and display - "Of myself, I have heard much ; I appreciate the honour, the esteem, and the regarl entertained for me by my successors. MIy work has accomplished all that I could have hoped for or desired. Tell me, then, if you can, something of the profession which I love so well."

To scarch out the Secrets of Nature. - Anxious to fulfil a wish so $\mathrm{nn}$ selfish an 1 disinterested, and remembering that Harvey had assigned to the Harveian Oration the duty of encouraging his fellows to search out the secrets of nature, it occurred to me that there are two of these secrets which, though not strictly of the kind to which our benefactor's words were intended to apply, are yet of sufficient interest and importunce to justify me in asking your attention to them for a bricf time to-day.

Why is Medicine depreciatcd? - The first of these secrets has reference to the past. Why is it that, amongst a vast number of persons, alike in ancient and in modern times, medicine has not enjoyed that high estimate of its valuc, as an art and as a science, to which it is justly entitled ?

What Prospect for the Future?-The other problem requires the exercise of the prophetic spirit; since I seek to ascertain whether we have any grounds for anticipating a more satisfactory future for our profession, either in the security of the foundations on which it is laid, or in the consequent appreciation of it by the public.

Why then is it that, both in ancient and modern times, medicinc has been so often regarded with scepticism and want of confidence, and so often treated with satire, and even with contempt ?

Difficulties incidcnt to the Hcaling Art. - In seeking an answer to this question, we cannot be surprised that scepticism as to the powers of the healing art should be rife, both within and without the profession, when we regard the nature of the problens with which we have to deal. The want of faith may be traced to tro sources : one intrinsic, and due to the inherent complexity and difficulties of the sul.ject ; the other accidental, external, to be found amongst the people: at large. In its scientific aspect, medicine possesse's this peculiar difficulty and source of uncertainty : that the indiviluals or units with which we have to deal not only differ from each other, but also vary constantly, each one within itself. They are sulject to endless. influences from within and from without, mental or physical, inherited or acquired. This ceaseless change of circumstance's, and the variations consequent upon it, complicate and confuse the problems pre. sented to the scientific physician, increase the labour of his investigations, and render his conclusicns so far uncertain that only repeateil verification can bring satisfaction to his mind. This source of difticulty is, however, so fullv appreciated by those whom I now address, and by all, indeed, who are interested in the pursuit of science, that I do not propose to dwell upon it here, but rather to turn to what I have callerl the external causes, which, by affecting the feclings und judgment of the masses, have frequently thrown doubt and discredit upon our professional proceedlings.

Exctrinsic Causes of Discredit on our Professim. - Evidence of the existence of such doubt; $h_{0} \mathrm{~h}$ in the past and in the present, is to be 
found in the judgments of men of science, not excluding indeed mem. bers of our own profession; in the sarcasms of dramatists and satirists; and still more in the daily action and behaviour of the sick, who, by submitting themselves to the treatment and by accepting the nostrums of charlatans and quacks, in the same spirit in which they would have recourse to our own aid, manifest the equal esteem in whith they hold us all.

Expressions of Adlerse Opinion. - I can best address myself to my argument by recalling to your memory some of the oft-quoted sentiments which, in tlie half truths they have expressed, indicate the aspect in which our art has appeared to thoughtful minds

"Quot Themison ityros aut unno oceiderit uno?'

asks Juvenal satirically, in reference to the lesding practitioner of his day-an expression which has leen parodied in our own tinues by an eminent statesman, who askel his friend and physician how many deer ho had killed during his nutumnal holiday; and, on being told a dozen or more, exclaimed, "I congratulate you; you could not have had more success amongst your patients!" Turning to our profession, we find Cclsus asserting that "optima unedicina est non uti unsdicinit." Even Hoffinann exclaimed, " Fuge medicos et medicamenta si vis esse salvus." Dr. Gregory, half a century ago, expressed a remarkable opinion, not more discouraging to his profession as a physician than damaging to his reputation as a prophet, when he said, "I think it more than possible that, in fifty or a hundred years, the business of physician will not be regarded even in England as either a learned or a liberal profession." Magendic once statel that " the doctor is often superlluous, sometimes mischievous, and occasionally fatal."

It was not likely we should escape from Shakespeare's criticism. "Trust not the physician," said Timon to the banditti ; "his antidotes are poisons, and he slays more than you rob." The opinion entertained of nur profession by Molière is too familiar to need repetition ; whilst Voltaire tersely described our practice as " pouring drugs of which we know little into bollies of which we know less." The late Dr. Arnold wrote, not so long ago: "The philosopiny of medicine, I imagine, is almost at zero; our practice is empirical, and secms hardly more than a course of guessing, more or less happy." I might easily oxtend this list, but there is probably no question more comprehensive and more damaging in its inference than that asked by the late Sir William Hamilton: "Has the practice of medicine made a single step since Hippocrates?" Embodying, as it docs, the essence of ad. verse criticism, and coming from so high an authority, I nevertheless hope to succeel in showing how utterly unfounded is the suggestion which it embodies.

The tone of low esteem which runs throughout these quotations, often the reflex of current opinion, as well as of that of the individual, compels an attempt on our part to trace the causes to which it may be attributed. These, I think, may be considered as threcfold in their character : first, the very course and progress of the science and art of medicine itself from the earliest times to the present day secondly, the ansaring crellulity of the mass of mankind ; and, thirdly, the obstinate and unreasoning incredulity of no inconsiderable minority.

Origin and Course of the Ilealing Art.-In looking back on the history of our art, we may remember how it was believed to have emerged from the clouds, and how those who practised it wero regarded as gods ; how, subsequently, in the hands of Hippocrates, the art first assumed the form of a seience, and was, by hin and his immediate successors, pursued on a line of carcful observation, influenced by, but not entirely subjugated to, the prevailing philosophical speculations on the nature of things ; low, further, impeded in its origin, it becamo for centuries the prey of rival systems, which, based on a priori speculations, and founded on ignorance, were made to fit in with notions enreulered by imperfect knowledge. The more mention of some of these systems is sullicient to suggest the absurdities they propounded, and to justify the taunts and sneers of chose who, cven could they accept the doctrines set forth, were shaken in thoir faith when they witnessed rival sects strenuously contending each for its own infallibility. Galen strongly condemned the distinctions made by these sects, as leading to interminable hypotheses and disputes, in which each individual supported his own theory to the disparagement of others, and to the great injury of medicinc in general.

How, then, ran we blame the critic who was bewilderel by the rival factions of dormatists, empirics, methodists, pneumatists, and eclecties, together with the many others in whese hands medicine was "reducel to a mere denartment of speculative philosophy, involved in futile disputations and in formulas based on no substan. tial facts," and who for six centuries practically monopolised the heal. ing art? 'Through the dark ages, during which medicine was largely under Arabic influence, our saience consisted, for the most part, of wordy commentaries on the writings of the ancients; and the practice, mainly confined to the priesthood, was regulated by the grossest superstition. Those were the days of the astrologer and miracleworker, of cures by prayers, relics, and royal touch, and of the search for the elixir vitw, the time when surgery was in the hands of barbers.

Revival of Seience and lcarning. - But it must not be forgotten that, during this very period, when all science was at a standstill, and when we can searcely point to a single observation or discovery, the unirersities were founded, and, in the hands of a few, in small and scattered schools, the light of investigation, although dimmed in the prevailing atmosphere of mysticism and hypothesis, had been kindled and wus kept alive ; notably at Salernum, where an attempt was made to substitute a scicntific procedure for the generally prevalent superstitions. At Bologna, Padua, and other schools, anatomy, long discarded, was again beginning to be studied; and thus the revival of learning, and the foundation of the modern scientific method by Bacon, did not find our art absolutely unprepared to receive them. None the less, in Harvey's day, the whole work liad to be begun anew; the preceding centuries had been almost so much lost time, all that had been handel down from them in the shape of fact was of the most meagre character; dissection had fullen into disuse; without knowledge of structure, there could be no physiology, still less any rational pathology and diagnosis; and all that existed of therapeutics was the empirical kuowledge of the efficacy of a certain number of drugs.

Linacre and thr Fonzudution of th: College of Physicinns. - It was not long, however, before improvement reached us. In 1518, Linacre, who had studed at Salernum, returned to found our College by ob. taining, through Wolsey's influenco with Henry VIII, the charter "whereby medicine was rescued frem the tender mercies of the ecelesiastical profession."

Progress of M/celical Si ince subserueriet to the Foundation of the Collerge. - The history of our profession from this time presents a record of ever increasing additions to our knowledge, acquired by careful observation and experiment. Each division of our complex science received a fresh impetus, not a few becoming differentiated and distirct, and all pursuing for the ncxt two centuries a path of unintorrupted progress. Anatomy, which Vesalius, Fallopius, Fabricius, and others had built un, reached, in the hands of their successors, a degree of precision only limited by the nature of the subject. Physiolngy, which can scarcely claim to have been a scparate branch before Haller, was pursued with increasing energy by Hunter, Spallanzani, Hewson, and many others. To Sydenham, Baglivi, and notably IBoerhaave, may be ascribed the merit of applying to medicine the method of ob. servation which may be said to have been dormant since the days of Hippocrates. Morbid anatomy, which first took shape in the hands of Bonetus, and was developed by the labours of Morgagni, mora than sustained its position by the labours of the Hunters, of our illustrious Fellow, Mathew Baillie, and of many eminent French pathologists. Thus, then, did every branch of our science make progress. Uniortunately, however, incidental to this progress, often inseparable from it, and always detrimental to it, there has continued a tendency to system-making and speculating of the shallowest and most specious character. I am not concerned with the causes which occasioned the delusions hence arising, nor with the justification they might plead for their existence in times when superstition and credulity were rife; it is sufficient for my argument that they existed, and that they con. tributed, not without reason, to the low esteem in which the efforts of even the foremost of our profession were held. But, whilst the true science which budded forth with Hippocrates was stifled by the sys. tems of his successors, its revival with Harvey and his contemporaries was too powerful to suffer the same fatc; henceforth the vain imaginings ran their course side by side with the progress of scientific truth, frequently to its hindrance and injury, but still more frequently to be cast aside and forgotten.

Sources aind Phases of Superstitivin. - The sources of the various superstitions which degraded our science, and which even still afford some ground for scepticism, are to be sought, not only in tho inherent tendency of the human mind to accept the marvellous and supernatural, to court deception, and to be pleased rather than otherwise with the result of its quest-quandoquidem populus decipi vult, decipiatur-but also in the admitted influence of the imagination over certain functions of the body. The simple, and to us fairly intelligible, occurrence of the occasional removal of pain by a concentration of the attention elsewhere, or by the substitution for it of some strong omotion, may account for much that, in the past no less than in the present, has become preposterous and absurd from the lengths to which it has been carricd. With such material to work upon, it was and 
contimbs assy for designing chrorlatans, or mistaken zealo tos; to devedop the most outrageous hypotheses and practices.

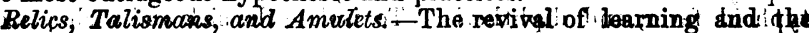
scientific method, whilst lighting ap the path for the few, left ithe masses untouched; and the superstitions which somewhat loins placently refer to the dark ages remdined unaffected by thei resulti that: aocurate observation was producing. Tho practice of the bebling urt was not yet intirely removed from the : hands of the priesthogd? and the treatment of disease by supplications, by the laying on to hiands, by the power of relics, shrines; and holy wells, found still, its administrators and its dupes. The superstition of the curative virtures resident in sacred things was easily extended to objects intrinsically lews reverend in their nature; and taligmanis of atone, metal, or nood, ongrared with cabalistic signs; of phythateries, which were texts

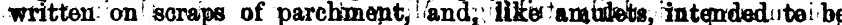
worn on the person, were easily aequired adjwnets'to the necessarily limited supply of saintly relics. And yet who sfíll say that $a$. tithe which has produced claistopance; metallia tractops, and the " mind lovive," is free to cast repirpach at the debds of theod dark ages i.

Astrology and Abdremy:-The 'whole so-called! cabelistic sciences of watrology and alchemy; developed as they were by men of ability like Parcolsus, came to didure aistrength which thoy would scarcely have possessed if left alone: tho the ignorance of the people. John French, in a work on alchemplpublished in 1850 , and supposed to have been among the last on the subject, thns enunciates the pretensions of of his cratt : "If men did but believe what this art could effect, and what variety of wonder there is in it, they would no.longer be bonind up to Galen or Aristotle, but would subscribe to be faithel to the prineiples of Hermes and Paracelsus."

The Royal Touch.-Perhaps among the most curious of all the superstitions that have debased our profession, is that of the royal gift of healing. Commencing witii Edward the Confessor, the touch continned to be practised by our sovereigns, though with many excep tions, until the days of the first George. Nor : was it limited, to this contry. France claims Clovis as the originator, and the ceremony was certainly performed by many of his suecessors. "In no reign,?" says Dr. Pettigrew, "did the practice prevail to such an extent as in that of Charles $I_{y}$ and it is not a littlo renarkable' that more people died of scrofflai, secording to therbills of mortality, during this period than in any other." It may be further observed that surgeons did nót disdain to recommend this treatment to their patients. It was at the instigation of Sìr John Floyer, a physician of eminence, that Samuel Johnson was twice " touched" by Queen Anne; and, as Boswell remaxked, evidently without success. This power has not been held to be limited to royalty: "Even to-day," wrote the late Dr. Meryon, "in Scotland the seventh male child in a family has the gift of curing the kimg's evil by touch:"

Credulity. -The existence of these and a thousand other superstitions, the record of which excites alike our amusement and amaze ment, could not have boen sustained for a moment except for the credulity of those" on whom they were practised. "The kind o credulity," says Bir James Simpson, "which the public thus show daily in relation to medicine, they show in relation to no other prac tical art or science: Indeed, if a similar species of charlatanry were attem pted in relation to most other arts and sciences, the delusion would be at once deteoted, and the imposture duly denounced; whilst, in medicine, the delusion would, on the other : hand, probably make the propounder's fame and fortune, and in the course of years be forgotten. Truly we may say with Crabbo-

$$
\text { This love of lufe, which in oue nature raies, }
$$

Td vile imposture makes us dapes and fools."

Aspect of the College in Relation to Supperstitionss Practices.-So wide spread and importunate were these errors, that we find even our own College gravely testing men in their knowledge of astrology (1593-96), deputing members of our body to inspect bewitched people, and summoning those who assumed the power of cure by touch, requiring them to exercise their skill in the presence of the College.

It is not to be forgotten that Harvey himself following on the lines of Galen and Aristotle, adopted a view as to the nature of life which is a phase of the almost universal conception held in one form or another up to our own day. It appeared as' the "animism" of Hoffmann and Stahl, who bequeathed to us, as a consequence, what is known as "expectant medicine." Another development of the same idea is the theory of a vital principle, the "vitalism" of Haller and Barthez, from which even now we cannat be said to be entirely free.

Modern Systems. Oullen, Bronon, Broussais; Homoopathoy.-Scarcely mone than a century ago, the medical world was divided by the contending schools of 'Cullen and Brown : the latter with his sthenic and astheric diseases and tonic and depressamt itrastanght; tho formar; in bot hdstility, ad woeating the hypothesis that disease was the pesult of

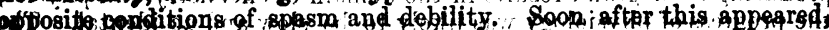

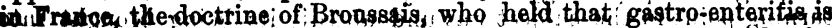
tho rrbagis of pathology, and local idepletion the praper romedy $f O A$ Sover', There is yet anothor systom which cannotibe passed over withe ont, neforence, namely, hommopath y, IWhich teaches, that disease con

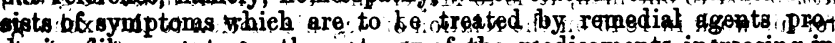
dhaing like symptoms, the poteney of the medieaments incressing in proportion to: their dilution.

The Influence of Superstition and System in Discrediting the Heat. ing id the-The influence which thase myths have had upon ' the heel ingi art has been most vgriod i / But certainly they have played a larga part in occedsioming the low negard in which practitioners of medicino Tave tod of ten been held by the pablic. I oannot do better, perhaps, then quote the words of Dr. Percival, who said: "A list of all the fallies which at different periods have beep established gs articles of

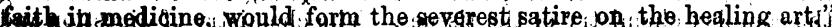
inofritits seached by Observers bsfone the: Rocsent Agtad-But, despite alf thes untaward influences, the progress, as I have neminded (yow, wasi eound so far as it went, when wo considet the dilsd vantages under which the workers purswed thein , investigations , Nevertheless, thesy come to a line, beyond which they made but slight advance, a line indistinct perhaps, and not equally sharr and well:defined in eyery anjjact, but withal a line across which, withput the intervention of rome great change, they could never havel passed. We may.apply ${ }_{i}$ to this perjod the words that Bacon used in reforense to seience 11 i Igeneral in a previous age. "Learning is neither tpyospexoup por greatly advenced, and a way must be opened to the human understanding entirely diatinet from that known to our pradecessors, and different aids procured, that the mind may exereise her power oper the nature of things.

looking back, as I can, to the mannet in which the oemponent pants of the medical curriculum were pharsued, when il ibegan m atudent life, and contrasting this manner, with what goes on anound me.now, I eannot doubt, in the words of Baodn that new Way, has been opened-an instauratio magna. Wher I tell some of my youngar listeners that only forty-six years aco the late Sir Robart Carswell, the first pathologist of his day, whose idramings of toorbid appeananees remgin a monument of accuracy and skill, never used microscope in his course of lectures, and that his only refenence to microscopie anpearances was to mention that pas' conisists of a clear fluid and globules, some idea may be formed of the change which has taken. place.

Direction of the Change that has Occarred-And now, during: fow moments lat me indicate to fou; the direction.in which this change has been effected, seeking, imoanthile; if wo may fiud therein any data which may help us to reply to mas. second question--What are our hopes for the future? Clearly the direction was towards a batter comprehersion of the nature of lifey and inferentially, of disease; tagether with a more accurate kingwhedge of the ibody, both in its atruetare and its functions. Tho halt to which obsedvens had come was largely compelled by narrow. methods of experimient; and it is particulaxly to improvement in the methods and idstruments of resoarch that magh of, own advance is, to be attributed, as, it is also from such improvement that still more is to be expected.

Aratomy and Histology. First' in respect to gross anatomy, the science of structure, little could be added to the knowledge which has ween continuouslyaceumulated since the deys to which I havepreviously referred ; but it was Bichat who; in 1801, by his treatise on the minute anatomy of the tissues, opened up a new/branch of inquiry which, but for the microscope, could not have existed, and forwhich the microscope has done, what the reflecting telescope did for astronomy. "It would nat $800 \mathrm{~m}$, however, that the work of himself and his followers had borne much practieal fruit, even in my early days. I have told yon what was then the state of the microscope in' refer 3 noce to morbid anatomy: Its position in respect to healthy histology was scarcel better; and it is only gince then that the impetus for investigation has arisen, and the applieation of this rimpetus to physiology. Prominont among the researches into struotnxe, was the recognition by Schwann and Schleiden of the so-called cell in 'all liring tissues ; doctrine which has been subsequently extended to enbrace the existence of protoplasmic forms! getherall folli I ned hot mare than mention the very considerahle position, bath ais regards extent and accuracy, which hiatology has assumed within the past few ear

Physiology.-So long as the study of the phenomenp of the living body was hampered by the dominant notion of at special vital prin ciple, not amenable to the laws which governed inert matter, and 
which was to be investigated in ways other than those which were producing such grand results in the domain of ehemistry ynd physics the progress of physiology was likely to be slow and accidertalicutipe turning point in the subject was undoubtedly its being broughtintio harmony with the principles which govern other experimental scioncebs and being pursued along the same path. So far as the change can ib attributed to one man, it is to Mayer that this credit must be given; for his work in 1845 on the relation of organic motion to the exchange of material. For some time from that date, no function of the bodly escaped investigation by a method of direct experiment, of of high mistaken humanity and senseless clamour have since deprived ius, always aided by the experiments which nature offers to the physiblogist in tho shape of disease, complicated though they be by conditions which render them more difficult of explanation. From the ehendiead side, physiology has received much assistance. Our knbwhedge of the composition of the blood and its derived secretions, though ratill leaving much to be desired, has done something towards unvavelling the complex chemistry of the tissues. The chemistry of digestion and respiration, which, a century-nay, fifty years-ago, was a jargon compounded of the residues of the Hippocratic notion of the four elements, and of alchemy, interspersed with streaks of the new chemintry which was then arising, is now pursued on lines in harmony with those of every day laboratory investigation. To mention but one practical result thence obtained, I would refer to the artifidial digtestivo juices and prepared foods which are among the most, valuable of our remedies. On the physical side are the study of the phenomene of muscular contractility, and the expression of the work done in such terms, that it may be calculated with the same accuracy the fuel value of a pound of coals; the study of the laws of osmosis; which underlie all the physiology of absorption and nutrition; the conditions affecting and determining gaseous interchange, which explain the process of respiration; the nature of elasticity, and the important : ghape it takes in the physies of the circulation ; turn which way we will, we woo now in our physiological laboratories-themselves the creation of the last twenty years-experimenter and instrument-maker competing in a demiand and supply of the apparatus by which such work as I have indicated has been rendered possible.

Pathology. - To speak of the advance of physiology is to imply a progress in pathology, since the latter is but the application of the former under the conditions of disease. Mutually aiding each other as they have done, it was not until physiology was on a secure / foundation that pathology could claim the title of rational: Although healthy structure came to be known, and the dependence upon it of function to be recognised, it was long before the same idea prevailed in respect to disease. It is the especial glory of Virchow's work on cellular pathology, that he applied consistently to morbid structure and action the same principles which had already made considerable advance in regard to health.

Etiology. - Proceeding on such lines, lines that we feel assured are tending towards great truths, we find that in every branch into which pathology is artificially separated improvement is taking place. The causation of disease-etiology-it is now known, must be sought in disturbances of our environment, or in defective inherited tendencies. How immeasurable is the distance which separates the mental attitude of the inquirer of to-day, engaged in tracing the causation of an epidemic disease, from the mystics who bewildered themselves with the notions of malignant spirits, evil humours, or even now of epidemic wares.

Illustration of Preventive Medicine.-To illustrate especially the advance we have made in our knowledge of etiology, I would select but one point, which is the practice of arresting the diffusion of disease by limiting the spread of contagion.

Cattle-Plague. - This practice was illustrated on a gigantic scale by the rinderpest or cattle-plague, which appeared in this country in 1865. Towards the end of June in that year, a few bulloeks, imported from Revel, bringing with them the infection of eattle-plague, were sold in the Metropolitan Cattle Market. From this single centre, the disease spread throughout the country, until it had estab. lished 25,000 foci of infection within the year. Then a remedy was applied. All traffic of cattle was stopped; all infected weasts were killed, and all healthy bovine animals with which they had cone into contact. The pestilence was stayed, but not until 300,000 animals had died or been killed, with a loss to the country, at a low estimate of $£ 3,000,000$ sterling, and an indirect loss to the same amount. All this might have been spared if it had been possible for the atuthorities, by $x$ better knowledge of the nature of the disease, to extinguish it at its single primary focus by the sacrifice of a small number of animals at the cost of a few pounds.

Cholera. - The system of preventive treatment which thus proved so enceessfut in the case of the lower animals has, as far as may be, been employed in certain infectious diseases, such as cholera, searlet fever, typhoid ferer, and diphtheria. To isolate the sick and such perans as hated been in relation with them, until the very end of the period of infection; to thoroughly disinfect the secretions and other products from the patient at the earliest possible moment; to properly diopose of the dead; to cut off from the public all sources of contaminated stpply, whether of water, milk, or other kind of food-these are a few of the principal measures which the experience of a comparatively recent period thas taught us to practise in contagious diseases, with results so satisfactory as to encourage us in their further extension. We have rational grounds for the belief that, if the spread of infection were restrieted by law, this class of diseases would soon be effectually extinguished: The result of such, messures in reference to cholerapoison are particularly striking. Many of us remember the invasions of this eountry by chodera, and its fatal progress, in the years 1831 1847, and 1854. When sanitary measures were yet in their infancy the epidemic of 1866, though grave in certain districts-Swansea, for example-was rendered harmlees in other places. From that period to the present, there has been no serious outbreak of cholera in this country; although there have been infectious arrivals on our shores on several occasions, as in 1873 and 1884 at Southampton, Swansea, Liverpool, and in the Thames. This satisfactory result is entirely due to the efficient arrangements made by the proper authorities to limit the spread of the disease. In this matter they acted under, and carried out, the judicious counsel given by that wise administrator, Mr. Simon, when acting as medical adviser to the Privy Council and the Local Government Board. I need scarcely add that this teaching has not been lost upon Mr. Simon's former colleagues and able successors.

Small:Pox. - Nor would it be satisfactory for me to pass over the subject of raccination, the procedure by which that dire disease small-pox may be prevented or modified. " One fact is worth a ship-load of arguments ; $"$ and therefore it will be sufficient to say that Ireland, atated to be the lest vaccinated country in the world, is practically at this moment free from small-pox ; that, since 1874, not a single caise of death from variola has occuired in the German army, which dwells in the midst of a population protected by compulsory revaccination; whilst, on the other hand, we see at this moment, in the city of Montreal, unprotected by vaccination, a frightful mortality. It is painful to contemplate such a consequence of ignorance or neglect; but, as $\mathrm{Mr}$. Simon said in his letter on vaccination to the President of the General Board of Health, "it goes with the credulity. which eharacterises the present age to be incredulous of proved truth. Alike in rejecting what is known and in believing what ispreposterous, therights of private foolishness assert themselves. It is but the samo impotence of judgment which shrinks from embracing what is real, and lavishes itself upon clouds of fiction."

Progress of Pathology. - I feel, sir, that it would be almost impertinent in me to address such an audience as I see before me on the details of the improvements in our knowledge of pathology and the allied subjects, the diagnosis and treatment of disease ; but, when I recall the views quoted by me in an early portion of this address, as to the absence of present progress of our science, and the hopelessness of its future-when I recall that these opinions have been held not only by men of science, but by many others-I feel it to be one of the duties of the present occasion to indicate our real position in definite language, the echo of which may possibly be heard beyond these walls. It will, at least, reach the ears of some one who will hear with satisfaction that the reproaches rajsed against us have no longer any foundation, and that the progress of our art and of our science has been greater during the last half-century than during all the preceding centuries. Nay, more; that recent progress gives promise of still more rapid progress in the future.

It is not necessary to recount an elaborate list of discoveries in suppoit of this assertion. One may safely say that there is no organ, no structure, no function of the body in health or disease, which has not received the stamp of improved knowledge during the period referred to.

The Work of the Pathological Society.-In our knowledge of the structural changes which occur in disease, accuracy is now replacing
with grcat strides the previous uncertainty and vagueness; and I foel it is due, in this connection, to refer to the good work of the Pathological Society of London, whose forty volumes of Transactions are a brilliant monument of labour and research, and a bright exemplar to future years. It is but justice to say, in memory of one long since dead, that the Society was established in 1843 by the intelligent zeal of a member of our College, the late Dr. Edward Bentley, a name which will be remembered and honoured by those of his friends and 
colleagues who yet survive, although unheard of or forgotten by:many who fully appreciate the value of the Society which he was the chief means of establishing.

Morbid Anatomy.-I need but remind you how extensive has become our knowledge within the past few years of the facts of structure revealed by the microscope in connection with new growths, with regard not only to their distinctive characteristics, but also those which connect apparently diverse forms, and indicate their relation to the tissues in which they occur. The structural lesions comprised in the term "degeneration" are now clearly recognised and defined; and, without pretending to a complete knowledge of these morbid conditions, that which we do know about them possesses 2 character of certainty and truth, dependent on the essentially correct method by which the facts have been determined.

Morbid Processes. - Concurrently with the growth and diffusion of a scientific knowledge of the causation of disease, and of its structura manifestations, there has arisen a better understanding of morbid processes. The condition of inflammation, which has been recogaised from the earliest times, and has probably given rise to. more discussion than any other subject in pathology, is now regarded in a manner which, whilst it admittedly leaves much to be discovered, is at least in harmony with our knowledge of the functions of normal nutrition. The pathology of fever also, though not yet complete, may be said to have been scientifically studied during the last fifty years. The systematic use of the clinical thermometer, the application of chemical testing to the secretions, and the improvements in the methods of bedside investigation generally, have revealed to us a vast number of facts which were unknown to observers at the beginning of the century. Another factor of the greatest importance, both in relation to normal function and to disease, is the direct influence exercised by the nervous system on the tissue-metabolism. We have no clear knowledge how this influence is exercised, but the existence of some control is certain ; and it is curious to notice how older notions of neural pathology recur in the more accurately defined conceptions of to-day. The comprehension of the part played by the blood in disease is also an advance which has been eminently fruitful in results, and which differs widely from the doctrine that at one time attributed every malady to some vitiated condition of the circulating fluid.

Parasitic Pathology. - But nothing will bring the conviction of recent progress more completely home to our minds than a brief retrospect of parasitic pathology during the last forty or fifty years. How great a step, though it looked but small at the time, was the discovery of the first vegetable parasite in the skin and hairs, by Gruby and others, about the year 1840. The notion of parasiticism as a cause of disease has clung to pathology in all ages; and the analogy between fermentation and the acute specific processes, had long possessed the mind of every thoughtful physician. But we ought clearly to bear in mind, in justice to modern medicine, that the Torula Cerevisiæ itself was not discoverod until 1835, by Schwann and others, and that it is only within the last few years that the presence and activity of an organism have, been definitely connected with a specific febrile disease-I refer to the discovery of the spirillum of relapsing fever by Obermeier in 1873. A new era in pathology, whatever may be its result, has arisen within the last few years with the rise of bacteriology. Following their master Koch, a host of highly trained and eager observers in Germany, France, England, and other countries, are now engaged in the study of the acute infective diseases, and by ever improving methods striving to contribute something fresh to the great, but still obscure and unsettled, subject of the relation of these organisms to pathology. Fallacious, no doubt, as were some of the earlier condusions on this subject, there seems to be no question that the study of bacteria and bacilli has greatly widenea our views of the nature of disease, and that it promises to lead to practical results of the first importance in its prevention or modification, as in the hands of Pasteur and others.

Experimental Pathology. - The value of all this progress has been greatly extended by the aid of that new line of scientific inquiry which has already done so much, and which promises still more-I mean experimental pathology. Of this subject, Hunter laid the foundations a hundred years ago; but it was reserved for our own time to see the extension of his method on a large scale in this country to the subjects of fever and infection-to the study of disease artificially produced, which, in the hands of Sanderson, Klein, Greenfield, and others, has been so materially promoted by the establishment of the Brown Institution.

Diagnosis. - Whilst pathology has been thus steadily progressing side by side with physiology, diagnosis, or symptomatology, the science and art of clinical observation has proportionately profited by our improved knowlelge of these snbject;. The leading feature of modern diagnosis is the full adoption of methods and instruments of seientific exactness, which, by the aid they give to the senses, the diseased organs may, as it were, be made to reveal their own condition.

Instruments of Diagnosis. - The stethoscope, introduced by Laennec in 1819, was used by but a few at the commencement of the second gnarter of this century; and I well remember how an eminent physician to St. George's Hospital, whom I met in consultation littlo more than thirty years ago, characterised it as a dangerous instrument. The aphthalmoscope, invaluable in the detection of diseases of the eye, reveals to us also many morbid conditions of the brain and spinal cord, and even more general disease, such as is represented by albumipuria. The laryngoscope is of equal value in reference to the diagmosis of diseases of the throat and chest. Instruments are now in constant use which accurately measure and graphically record the condition and movements of the several organs-the sphygmograph and cardiograph; whilst even the number and-value of the bloodglobules are revealed to us by the hæmacytometer and hæmoglobinometer. The general adoption of the clinical thermometer and of the electric battery has marked an era in medical diagnosis. The micrascope has become indispensable to the medical practitioner ; and eren the spectroscope has some clinical uses. The chemistry of the secretions is now universally practised, the routine examination of the urine having revealed to us a large number of interesting facts. On some of these I might have dwelt, had time allowed me; but. I can only refer in a word to the evidence which the examination of the urine furnishes of the remarkable relation which exists, in a great number of instances, not only between the liver and glycosuria, but between the liver and azoturia and albuminuria. The subject is one of deep and general interest, fully demanding investigation.

Special Progress in Diagnosis. - No advance has been more important than that of the differentiation of the several forms of fever, an advance to which you, sir, have yourself so largely contributed. The increase of our knowledge of the symptomatology of diseascs of the nervous system has been equally marked. In all directions we may note greater definiteness of knowledge and of diagnostic power. Many forms of disease, previously unknown, ate now rocognisable by the exercise of ordinary carefulness.

In a word, it may be said that those only who lived and practised in what may be called the pre-accurate period of medicine, and who are still ongaged in practice, can appreciate the vast improvements which have been introdnced in the course of a professional lifetime, in the art of the observation of disease, and can perceive how some of these are suggestive of still greater results in the future.

In speaking of the progress of medicine, I would, of course, be understood to include those departments which have been somewhat arbitiarily separated from it-surgery and gynecology. But, as special branches of the healing art, their advancement has been 80 considerable as to demand, for their full exposition, some one more competent for the duty than I have any claim to be.

Therapeutics. - I now come to a most important part of my present inquiry ; the practical application to treatment of the great advances which I have just recorded in the medical sciences. We must not forgot, in our enthusiasm as scientific observers, that our very raison d'etre as physicians is the prevention and cure of disease. With these two branches of practical medicine we are equally concerned: onr College has ever been as distinguished for its infuence in the one as in the other. As early as 1650 , the College presented to the Lords of the Council a statement of "Annoyances" by way of preservation from the plague, very similar, indeed, to what the College might suggest at the present day.

Two Directions of its Advance. - With reference to the question how far our methors of treatment of disease have been improved, I fear I must expect to meet with a certain amount of scepticism. But this scepticism is unreasonable. During the last fifty years, medicinal treatment has advanced in two directions : by the introduction of many new drugs of great importance, and by the conversion into rational remedies of a large number of substances which were previoully employed in a purely empirical manner. These results have been greatly facilitated by the discovery of the alkaloids, the first of which was mol phine, in 1817. With these and other active principles, the practical physician is able to determine with accuracy the value of drugs which possess definite physiological actions, and to apply them in a simple, uncomplicated form, especially by subcutaneous injections. Nay, more ; the pharmacologist is nolonger satisfied with the direct supply from nature; he is now busily engaged preparing synthetically a series of entirely new agents.

Intraduction of Anoesthetics. - There are those who, seeing no proress in therapeutics, must have forgotten that some of the most eff- 
clent means for diminishing human pain and suffering, the wholo olass of and thetics, commeneing with the applieation of otherin America in 1847, have been discovered within the last forty years! In this connection, also, I would mention the revival, on scientifit orinciples, of the adrininistration of nitrous oxide gas as an anæsthetic. Of atill more recent introduction are chloral-hydrate and cudaite Whilst nitrite of emyl; of sodium, and nitro glycerine' are recegnised 't: invaluable tents in the reduction of arterial tension.

"Special Drsogs:-The proper use of the bromides is comparatively new ; indeed "bromide of potassium was omitted fron the Lon Pharmacoporia of 1851 as being an useless drug.:" At the present time we find the dominerit idea in pathology, the doctrime of germs; ipey valding and influencing therapeutics also. Antiseptics, with which the name of lister is inseparably connected, and antipyretics, areberws ethployed' in treatment to an extent of which the last generation 'cotal not have dreamed, and with results of the greatest practical adtantaige: The introduction of the salicyl-compounds in the treatment of $\mathrm{xhet}$ nditiom is still a comparatively recent event. Some of the new ant xyrotic : drugs almost rivil in power quinine and salieine themselves Surely all this is improvement of the best kind. Let us pause for thoment, and contemiplate the condition and prospect of al surbical patient only'fifty years ago : no anæesthetic to induce inserisibility to pain', no antisepties' to promote healing of the wound; no chloral to procure sleep ; no antipy! etic in general ase to control fever. With sueh instances before us, how unjust to say, with some, that meaf? einal therapeatics remain stationary.

Future Prospeets of Therapeutics. - Turning now to the prospect for the future, I may be allowed to add a few words on the mears fir. which further therapeutical advance can be secured. There'are two lines of investigation which must be followed, namely, clinical ot servation and pharmocological research. We must not approach these itiquiries with the question, now too often heard, Have your biny fdith in physic ? but with minds free from prejudice and ireredtulity', shite hopeful of results not inferior to those which have characterised rectent investigations: It would be uribecoming in me to attempt to indicato in this a ssembly the naniver in which clinical observation of the'action of remedies should proceed. "BtPH, it seems to me that there are brie or two points which giteatly threaten, in practice, to interfere with the rational administration of remedies, and which I would desire to tebndetmin inastruch as they tend seriously to retard our fature.

Retarding Circumstances. - There has grown up a habit of presertibitig rebdy-made physic, of using compounds which contain'a tratiety' of drugs; each having different properties-a practice in which there is $\mathbf{d}$ mental proclivity to regard the disease as suitable to the physict in hand rather than to take the trouble to find a remedy that is "suitable to the disease. This system is tripractical, unscientific, and least

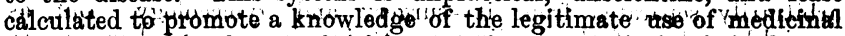
agetits. In fact, the art of writing a rational prescription is in dainger of becoming lost.

Closely copnected with the practice here condemned is that which hastily reptidiates remedies on the ground of their failing to fulfil the intentions which they have been prescribed. A chapter might je written 'on this'subject, which, however, I shall summarise by 'stid' in that'when these incidents cross my path-as they do thit of all of t's-I am disposed to fear that my diagnosis, and not the drug; has been at fatult.

Secondly, wo must regard with jeafousy what is called the statis. tical method of inquiry-that method in which an aggregate' bf tinits is made to represent a single substantial fact. If these units difter among themselves, and if the recorders of these single facts be'triot quite certain of the uniformity of the facts. with which they are dealing, the inference must be misleading. It was Morgagn who said that "facts must be weighed, not counted ;" and there is nothing pore certain than that, if this sage advice be not followed; the conclusions with be unsound. This is the danger to which what has beth "called "collective investigation" is liable. So long as the inquiry is confined to simple facts $w$ hich the observers are not likely to mistake, it is probable that valuable results may be obtained. But so soon ds the problems to be inquired into are such as demand a clear judgment and close reasoning for their solution, the capacity of the observits cómes into play as an important qualifying consideration in estimatin the valte of the results that are formulated. And when the method is appliad to obscure points difficult of verification-sueh; for example, as the hereditariness or the infectionsness of phthisis-the conclusions may easily be rendered mischievous and antrorthy of confidence.

Experimental Pharmacology. - Hating this spoken brieft of linical observation, the next method by which therapentical science can be advanced is that of experimental pharmacology-the scientific intestigation of the action of thedicinal agents on healthy animals: These two modes of inquiry should be carried on sintaltanobusly, edolh suggesting, and at the same time testing, the methods of reseateh pursued by the other.

By the aid of pharmacology, the circumstances of an experiment are greatiy'sins plified wo can vary the conditions under which it is condacted, and thas trace the numerous influences which either assist or counteract the action of drugs, and which lead to variable and apparently conflicting restilts in man. By this theans also we can determine which part of a complex mechanism, stech as the nervotis sy'stem is affected by perticular agents-whether; for example, the netrous centres, the nervous tracts, or the petipheral endings. And again, it is only by experiments on -animals' that we can safely test the action and strength of nev drugs, and the phenomena and morbid tesults prodiced by poisonous doses; whilst from such experiments we teceive many fresh' suggestions for 'the introduction or manufacture of allied products. In England, for the moment, we are compelled almost entirely to aceept sueh results at second-hand, legislstion interfering with this method of inquiry. We must revert to the liberty of aetion possessed by France, Germany, and other countries, or must send our inquirers to pursue science in plaees where they are free to do so without incurring legal perialties.

Position of the Oollege in Respect to Therapeutic Research. - The results of investigations such as these, too often baried in elaborate monographs, may never reach the physieian in a form to bring home their application to his mind and in his practice. How they might be made more popular and more available in our daily procedure, is a guestion which should claim attention within these walls. Our College might do much for the encouragement of research in therapenties, and we might tequire from the candidates for our licence a better knowledge of the subject. Fortunately, we have means which might be' made avdilable for promoting the first of these objeets in the funds detived from the Croonian Trust, recently increased in value. It is a grateful of uty to remember the name of the founder, Eady Sadier, a ditt strictly in aecord with the desire of Harvey' that, on these occasions, our benefactors should be duly commemorated. Lady Sadliter, in 1700 founded the Croonian Trust, a trast which estab: lished a lectureship remunetated by a yearly payment of £10. The property bequesthed to us has increased in thlue, and now affords the College an avilible income from this scurce of over 2200 a yedr. Harvey also desired that the Harreian orator should exhort the Fellots and Members of the College to search and stidy dew the secrets' of Nature by way of experiment. How could the Croonian fund, thus so' much increased in value, be appropriated with more justice; or with greater advantage than' in promoting the scientific study of the treatment of disease, the very object for whieh out College exists!

Secondly, soeing the large number of individuals who, through receiving the licence of this College, annually join the profession, it is quite within our power so to regulate the course of eduction and the examinations; as to vfring the subject of therepeuties into that position an the evrriculum in which it would receive the most practical and profitable consideration. And in mentioning the control thus abtained by the College over the medical profession, it is my pleasing duty to refer to those real benefactors who, in the year 1859 , re-established the class of licentiates; with a result which has enabled us, by the increase of our fands, to assume that independent position to which the College is justly entitled, but which, nevertheless, it had not previously enjoyed.

Nikvidence of the Improvement Claimed.-But, sir, whilst I have indicated to you, in the faint outline which alone time pernits, the progress which our scienee and our'art have made in every direction', tive aroment wonld be incomplete nnless I produced some evidence that the improvements on which I have insisted hate been productive of substantial results. We must not only elain to have' replaced blind -groping along the pathways of knowledge by a method based on reason and observation, in which we recognise the vature of our ignoxance as well as the extent of our acquirements ; but, as exponents of a practical science, we are bound to show that our progress has been real. This, I think, may be done, even though it be briefly. The first object of medicine; it has been well said, is to prevent disease, atid the next to cure or relieve it; and the nearer we approach to these epds; the more staccessful may we claim to be. The prevalence of disense is displayed in the returns of mortality and of sickness; and a reference to the pages of those masterpieces of vital statistics,' 'the Registrar-General's annual reports; will furnish is with ample data fot estimating the fincreasing volue of preventive and remedial medicine in improving health and lengthening life, or the incidental national gain in labour and wealth which proceeds therefrom. 
Diminishod Mortality.-During the farty-three years intervening

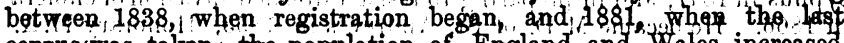
census was takpn, the population of England and Wales inereased from upwards of fifteen millions to nearly twenty-six millions, and all, ovidences of improved health should be convidered in reference to this total increase of population, as well as to such other influencing factors as the distribution in town and country, in respeot to sex-and age-periods.

Summarising the results of theso statistics, we note that there has boen a steady decline in the mean death-rate pen $1,0,00$ living from 23.3 in 1838 to 19.6 in 1884 . The decrease is stil mone strikingly shown if we compare the mean rate for the thirty seven years preceding 1875, when the Public Health Act bocame la, which was 22, 3, with that for the succoeding eight years, when it fell to 20.3 .

Taking the mean death-rate for the forty-five years from 1838 to 1883 , as 22.0 per 1,000 living, the improzement, within each of the past four years has been considerable : in 1881 it wes 18.9 ; in $1882,19.6$; in $1883,19.5$; and in 188 i 19.6 . This means that, if the death-rate of the previous decade; which mas 21.4, had been maintained, the deaths in England and Wales, during the four years in question, would have been nearly 218,000 more, than they actually: were.

The decline in the rate of mortality has occurred at all ages except from 45 to 75 in males, and from 55 to 65 in females; the greatest improvement occurring in both sexes at ages below five Jears Mr. Noel Humphreys, in an able paper on this subject, concludes that the effect of this decline in the death-rate is to raise the mean duration of life among males to the extent of two years, and among females to nearly three years and a half; and further, that by far the larger proportion of the increased duration of life in England and Wales is lived at useful ages, and not in the dependent conditions of childhood and old age. More recently, Mr. Makuna points out that the diminution of mantality means also the survival to maturity of most of the saved infants and children, and useful fives to some of them And Dr. Longstaff cansiders that the tendency appears to be for useful working life to be increased, but for old age to be slowly? shortened.

In Special Diseases. - It is improsible for me here to consider ip detail how the diminisked mortality is distributed among different diseases, or to assign to the two factors of that improvement, better sanitation and better methods of treatment, their respactive shares in producing the result. But it is distinctly in those diseases: which are caused by insanitary conditions, and which are so far preventable, that the greatest, improvement has taken place. Following the main grouping of sickness adopted by the registrar-general, there has been a decline from the mean rate for the decade $1871-80$, during the years since 1880, in zymptio, parasitic, constitutional, depelopmental, and local disease. Only in dietetic diseases has there been a slight in erease. As regards special diseases, the diminished mortality has beep most marked in the group of fevers (typhus, typhoid, and simple con. tinued), and in phthisis.

I cannot refrain from dwelling for a few moments on the special applications of these generel results to well-defined classes; and for this purpose I will select the army, though the same truths could be established, I believe; in other classes also.

In the Army - The general death-rate of the army at home for the decade $1870-79$ was 56 per cont. below that before 1854 , and the rate for 1880 was 62 per cent. below it. And, again, whilst in 1880 the death-rate per 1,000 living was 17.6, in 1881 it was 14 ; in 1882, 11.8; and in 1883 it fell to 9.8

Professor Maelean, speaking lately at Netley, said, in respect to the European part of the Indian Army, that the mortality in 1859-60 was about 79 per 1,000 , whilst in 1882 the death-rate in all India, from all causes, was only 13.07 por 1,000. He further stated that he had known, in the "pre-sanitary age," dysentery kill 1 in 5 of those attacked ; and in a regiment with an average strength of 1,098 there has been as many as 2,497 admissions into hospitals in a year, with 104 deaths, chiefly from dysentery and hepatic abscess; whilst in 1883 , in the same part of India, out of 13,000 men only 3 , out of 590 cases of dysentery proved fatal.

To speak of such a change, and not to mention the name of Edmund Parkes, would be unjust alike to his memory, and to the fair claims of the profession which is itself honoured in calling him a member We may say of him as Idomenous, speaking of the wounded Machaon, said to Nestor

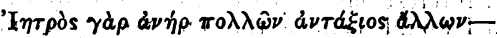
or; as Pope has rendered it,

"A. wise physician, skilled our wounds to heal,

Is thare the armies to the publio weal

Diminished Sicleness. The atatistics from which conclusione may be drawn as to the amount of sickness that prevails are necessarily im-

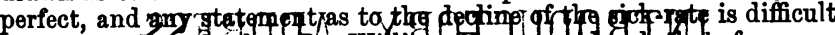

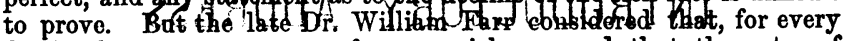
death, there are two cases of sevene sickness, and that the rates of mortality and gickness "" within ceprtain limits, rise and fall together." And since it is considered that for every death there are twenty-five

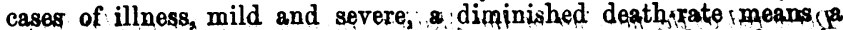
lessened amount of illness. The full significance of these facts in their bearing on our national wealth and productive power, as well as on the individual well-being und caphbility for work, can scarcely be overestimated; but these stbjoets litely received so:complete valtid admirable an exposition at the hands of Sir James Paget, that I need Iot farther allude to them here.

When we' thus ragard the rapid and marked progress which our ant and science have made during little more than half a century, I fol that we are fully justified in believing that progress in the future will be even more remarkable, and that, with materials for in vestigation in abundance, with willing and able workers, and with oft Coll lege aiding and guiding the work, there can be neither fear nor doubt for the continued advance of the healing art.

In en earlier portion of this address, I have mentioned thase wha have spoken in disparaging terms of our future. Let me pqM, on the other hand, refer to an opinion of greater interest and greater force, expressed recently by one of our most eminent statesmen, who has said to me, and repeated on more than one occision! : "Y ou prot fession has a great fature before it, and I believe that in the geherew tion, or at most two, it will be far in advance of the other learnad professions." This opinion is fully, in accord with our recent progress. There is before us a great future, and it is my faith in this future which has led me to speak to you in a sanguine spirit. I have done so in full reliance of the value of the results which will be accorn: plished ib those who are engaged in our great work, on the spirit which moves them, and on the means ; which they must $120 \theta$ at theirs disposal for investigation. I have spoken to Jou as, a prophet; but let nie add, in conclusion, one word of hope and of prayer: that at no distant period the Fellow of this Colloge, who has the privilege of oocupying the position which I have filled to:day, naty be 'able to speak to you no longer as a prophet, but as a historigh, Ito reetord the great work which had been acsomplished, and the share which opr College had taken in its achievement.

Wrarrerina ABROAD.-Among the many who will probably fly frotm land during: the coming winter, wo doubt if any will fidi" more enjoyable or economicat way of doing so than by taking advantage of the "five months" cruise in "a large steander which has been announced in our advertising columns for the paot few weeks; and as the programme embraces some of the most health-restoring and lavely isles in southern latitudes known to mediqal seience, there will be none of that monotony inseparable fram a voyage in a sailing ship. With cholera prevalent at, Nice and other parts of south France, as well as in Spain. Italy and Sicily we think some of our winter absentees will be well advised if (in pre fenence to going this season to their wsual haunts they vary their plan, and take a ticket for this sea-voyage. The fare, which is in clusive of everything except wines and spirits, which may hapurchaped on board is certainly very moderate, being only at the rate of $£ 1$ per day ; and as sea-voyages can effect astoniśhing cures when other means fail the present is a very favourable opportunity for, spch sufferers to derive the full, benefits of a well planned cruise; and wi feel ishre that many, who are now at a loss to know where to advise their patiopts to go for the winter will be glad to have, their attentign dinected to this trip, full particulars of which can be obtained at the Winter Cruise Office, 13, Lime Street, Londof, F.C.

Bequests AND Donations. - Mr. George Sturge has given 1,000 to the samaritan Fund of the Westminster Haspital the inoome of ; which in to,be paid to or for such in-patients as may be necessitoug, within three months of their discharge, for the purpose of their hating neces sary noumishment, elothing, or change of air-The Sussax Counto Hospital has received $£ 1,000$ under the will of $\mathbf{M r}_{\text {ic: William }}$ Beake, of Grand Parade, Brighton-Mr Hanson Freeman of Bilton Court, Knaresborough, has bequeathed 11,000 to the Halifax Infirmary:-T, The Adelaide Hospital, Dublini. has recejwed 2500 . under the will of Miss : Elizabeth Ross, and $£ 100$ under that of Mr, George Cagtles. The Lancaster. Infirmary and Dispensary has raceived 4500 under the will of Miss Susan Crompton-The Genenal Hospitad Birminghath, has seceived \&250 under the will of Mr.Peter Roxburgh and $£ 90$, under that of Mr. William Fleeming. 